\title{
Potential Benefits and Risks of Sewage Irrigation - A review
}

\author{
Monika Kharub
}

\begin{abstract}
Since 1950s, there have been dramatic developments in industry and an increase in urban population. As a result, the amount of disposal of industrial and domestic wastewater has increased with the passing of each year. A large number of farmers in the scarcity of water irrigate their land with sewage disposed wastewater and observed increased in yield of different crops as one of the benefits of sewage irrigation. This paper reviews the literature about the potential benefits and risks of sewage irrigation in agriculture sector with a discussion of the diseases caused by contaminated water. The current literature reveals that long term application of sewage irrigation to the agriculture section is not recommendable.
\end{abstract}

Index Terms - Sewage Irrigation; Agriculture, Plants, Soil, Productivity, Pathogens.

\section{INTRODUCTION}

Sewage irrigation may be defined as waste water containing sewage which can be used for irrigation in agriculture sector. It has been reported by (Anderson, 2004) that water pollution is more complex than air pollution because almost anything can be derelict into water including the kitchen waste. Sewage water contains a large variety of wastes ranging from domestic to industrial; therefore, the quality of such water is not suitable to irrigate any crop because of presence of many toxic chemicals (Ghafoor et al., 2004;). On the other hand, increasing efficacies in yields has increased demands on water resources for irrigation purposes.

It was noted by (Abdullah Arar) that the potential of irrigation water is increasing both for food production and the living standards of the rural people. Out of total world's arable land $13 \%$ comes under the agricultural irrigation. Crops in big regions cannot be grown without sewage irrigation.

Human wastes, including sewage effluent, are a widely used resource in many parts of the world. With the introduction of the water-carriage system for domestic wastewater in the middle of the 9th century, several European and North American cities adopted crop irrigation as their means of wastewater disposal. Sewage farms, as they were called, were used in the United Kingdom as early as 1865, the United States (1871), France (1872), Germany (1976), India (1877), Australia (1893) and Mexico (1904). Effluents are recycled in various countries of the world in irrigation (USEPA, 1992). The additional significant feature is that it helps in reducing the stress on the amount of water that needs to be extracted from environmental water sources (USEPA, 1992) for various purposes such as for agriculture. It is noted that metabolic activity of soil micro-organisms increased when sewage

(Corresponding Author) Monika kharub, Freelance Environment Consultant and Independent Researcher (India) effluent is used for irrigation practices (Meli et al., 2002).

\section{EFFECT ON SOIL PROPERTIES}

It was observed by (R. Malla et al., 2007) that sewage water irrigation improved physico-chemical properties and fertility status of soils. The metallic cations contamination of vegetable crops was observed to be below the maximum permissible limits. Diverse regions of World, has placed unembellished strains on the existing water resources different have environmental impacts. With good effect on soil properties, it is also the best possible way of recycling of drainage and wastewater and it will help in reducing stress on water bodies.

\section{A. Positive effects of sewage irrigation}

Supplying of sewage water to the agriculture sector has two-fold benefits. Firstly, it is the best and economic way of disposal of sewage effluent and the second it supplies a number of nutrients to the soil and hence increases its productivity (Wang et al., 2002). It has been reported that India supports more than $16 \%$ of the world's population with only $4 \%$ of the world's fresh water resources (Singh, 2003). Although, agriculture sector in the country is one of the major users of water, so water available for irrigation is likely to be decreased by $10-15 \%$ in next two decades (CWC, 2000). In this changing scenario, there is a strong need of reuse of domestic and industrial waste water in agriculture for irrigating crops. It has been noted that in India, total waste water generated per annum from 200 cities is about 2600 Mm3 (Kaul et al., 1989) and also the use of sewage effluents is increasing in irrigating agricultural sector particularly in the peri-urban area. The application of sewage effluent to spinach vegetable has shown a considerable positive effect on its production (Bashir et al., 2006) and increased the concentration of $\mathrm{N}$ and $\mathrm{P}$ in the plant components with increased concentration of sewage water (Mays et al., 1973). It has been estimated by (Ghafoor et al., 2004) that concentration of heavy metals in the leaves of spinach were above the permissible limits of WHO for those vegetable fields, which were irrigated by sewage water.

(Thomas V. Gloaguen, 2007) has been reported that irrigation is considered as a good alternative for sewage effluent use with the actual concerns for increasing use of water in agriculture, and there by the reducing stress on water resources, principally in tropical countries. A change in soil chemistry was observed as a short - term effect with the sewage effluent. So, irrigation with sewage effluent should be carefully done. Studies about changes in the chemical properties of soils irrigated with treated sewage effluent have mainly shown an increase of $\mathrm{Na}+$ and a fast oxidation of $\mathrm{NH} 4+$ 
into NO3 _ using subsurface dripping (Jnad et al., 2001). It was studied by (Jianwen et al., 2009) that greenhouse gas emissions from rice paddies under sewage irrigation deserve much attention since domestic sewage effluents are increasingly used for agriculture in developing countries. A field experiment on rice (Oryza sativa L.) paddies was done to check the emissions of methane $(\mathrm{CH} 4)$ and nitrous oxide (N2O). The results of the field experiment showed that rice supplied with sewage irrigation, showed increased $\mathrm{CH} 4$ by $27 \%$ and $33 \%$ with and without chemical $\mathrm{N}$ addition, in comparison to rice grown with unpolluted river water. It has been reported that sewage effluent contains good amounts of organic content along with essential macro and micronutrients (Carr et al., 2004; Xie et al., 2007). In addition, soil microbial communities and soil carbon and nitrogen processes were greatly influenced by sewage irrigation (Ndour et al., 2008).

It is noted that irrigation with primary effluent in some woody tree seedlings of Swietenia mahagoni during 18 months (2003-2004) was superior in improving the growth of plant height, growth of leaf area, growth of leaf number, positive response in fresh and dry weight of leaves, positive response in growth of shoots and roots and shoot/root ratio. Not only this, also the highest concentration and total acceptance of nitrogen, cadmium, potassium, nickel, phosphorus, lead and iron in plant parts, followed by secondary then tap water (Hayssam et al., 2011). A number of investigators, found that sewage effluent had a stimulatory effect on vegetative growth of trees, provided the soil physical characteristics, that reflected on the growth by enhancing the cell elongation and division (Ali et al. 2010) on Tipuana speciosa (Singh and Bhati, 2005) on Dalbergia sisoo.

\section{NEGATIVE EFFECTS OF SEWAGE IRRIGATION IN AGRICULTURE}

It has been investigated by (Owusu et al., 2012) that there is nearly relationship between physiognomies of farmers such as age, education and gender, and observations of health-related risks of farmers by the use of untreated wastewater use for irrigation practices. However, different studies carried out in response to sewage water irrigation indicates that constant use of such type of water depletes soil fertility and productivity. It has been reported that uncontrolled and untreated use of sewage irrigation can lead to increased concentration of heavy metals in the soil and increase the toxicity levels in plants (Williams et al., 1980). It is also observed that the Indian spinach irrigated with sewage water as such or its dilution increased organic carbon content of the soils while, in cauliflower and carrot calcium carbonate content was decreased. It was found that sewage irrigation increased tremendous yield of leafy vegetables but on the other hand it is reported that continuous use of sewage water in irrigation deteriorated soil fertility.

\section{VARIOUS RISKS OF RECYCLED EFFLUENT WATER}

Use of recycled sewage water can result in pathogens, viruses, bacterial, protozoal and heavy metal contamination problem. The pathogenic contamination (bacteria or viruses) is mostly associated with domestic sewage. (Ensink et al., 2004) has been reported that the presence of faecal coliform was $6.3 \times$
107 and $>1 \times 108$, and helminths eggs were 100 and 763, in the sewage of Haroonabad and Faisalabad. It was found viruses are one of the smallest disease casing micro-organisms found in wastewater and further entering into the host cells produce multiple copies of the virus (Toze, 1999). It has been reported that in recycled sewage water viruses are enteric which cause infections only in humans (Haas et al., 1999).

Also, the enteric bacteria are the most common of the microbial pathogens found in recycled waters (Toze, 1999). It has been reported by (Haas et al., 1999) that like other enteric pathogens, bacteria can also transfer from person to person, contaminated food and water. Such types of pathogens (bacterial pathogens) can infect both domestic and wild animals. Whereas, enteric protozoan pathogens are unicellular eukaryotes, which are obligate parasites. It has been reported by (Gennaccaro et al., 2003) that a large number of protozoan pathogens, found in recycled and waste water sources. A large number of different wild and domestic animals become infected with these protozoa. The other problem associated with the use of recycled water is salinity. The high salt concentration of recycled wastewater affects both the soil properties and plant growth. The effect of salinity in soil can be observed by the spectacles of dispersion and swelling. This effect of increasing sodium concentrations on clay is not uniform, but it may vary with similar soils (Halliwell et al., 2001). The reasons for these variations are multifaceted and involve competing properties including soil texture and mineralogy, bulk density, $\mathrm{pH}$, mechanical stresses and aggregate compulsory agents such as organic matter aluminium oxides and iron.

\section{A. Heavy metals}

A number of heavy metals are present in sewage effluent. It has been reported by (Chaudri et al.,2000) with application of sewage sludge or sewage water toxicity increase due to build-up of heavy metals, a reduction in species of rhizobia, $R$. leguminosarum bv. viciae and R. leguminosarum bv. Trifolii with decrease in legume nodulation was observed in soils which were contaminated with sewage sludge mainly with zinc and copper, or $\mathrm{Zn}$ plus $\mathrm{Cu}$ was applied.

Health - Crop irrigation with wastewater causes significant infection with intestinal nematodes in both consumers and those who work in such fields. A four to five-fold increase in hookworm infections was observed in regions of Faisalabad and Haroonabad (Ensink et al., 2004) who used wastewater. Also, diseases like Cholera and typhoid can be easily spread by irrigating vegetables with sewage effluent. Sixty-five number of disease outbreaks cases were reported in relation to food polluted by sewage irrigation (Bryan, 1977). The major number of cases were found to have typhoid, fever, viral hepatitis, helminthes infections (mostly fascioliasis), salmonella and cholera.

Table 1: FAO guidelines for reuse of treated water in agriculture sector

\begin{tabular}{|l|l|l|}
\hline $\begin{array}{l}\text { Type of } \\
\text { Agricultural } \\
\text { Reuse }\end{array}$ & $\begin{array}{l}\text { Type of } \\
\text { Treatment }\end{array}$ & Quality Criterion \\
\hline
\end{tabular}




\begin{tabular}{|c|c|c|}
\hline $\begin{array}{l}\text { Agricultural } \\
\text { reuse in crops } \\
\text { that are } \\
\text { consumed and } \\
\text { not processed } \\
\text { commercially }\end{array}$ & $\begin{array}{c}\text { Secondary } \\
\text { Filtration-D } \\
\text { isinfection }\end{array}$ & $\begin{array}{l}\mathrm{pH}=6.5-8.4 \\
\mathrm{BOD}<10 \mathrm{mg} / \mathrm{L} \\
<2 \mathrm{UNT} \\
<14 \mathrm{NMP} \text { E.coli/100 } \\
\mathrm{mL} \\
<1 \mathrm{Egg} / \mathrm{L}\end{array}$ \\
\hline $\begin{array}{l}\text { Agricultural } \\
\text { reuse in crops } \\
\text { that are } \\
\text { consumed and } \\
\text { not processed } \\
\text { commercially }\end{array}$ & $\begin{array}{l}\text { Secondary- } \\
\text { Disinfection }\end{array}$ & $\begin{array}{l}\mathrm{pH}=6.5-8.4 \\
\mathrm{BOD}<30 \mathrm{mg} / \mathrm{L} \\
\mathrm{SS}<30 \mathrm{mg} / \mathrm{L} \\
<200 \mathrm{NMP} \text {. coli/100 } \\
\mathrm{Ml}\end{array}$ \\
\hline $\begin{array}{l}\text { Agricultural } \\
\text { reuse in crops } \\
\text { that are not } \\
\text { consumed }\end{array}$ & $\begin{array}{l}\text { Secondary- } \\
\text { Disinfection }\end{array}$ & $\begin{array}{l}\mathrm{pH}=6.5-8.4 \\
\mathrm{BOD}<30 \mathrm{mg} / \mathrm{L} \\
\mathrm{SS}<30 \mathrm{mg} / \mathrm{L} \\
<200 \mathrm{NMP} \text { E. coli/100 } \\
\mathrm{mL}\end{array}$ \\
\hline
\end{tabular}

Source: FAO [41]

Metals already in phyto-toxic concentration in soils $(\mathrm{Cd}, \mathrm{Cr}$, $\mathrm{Pb}$ ) have similar plant accumulation trends as $\mathrm{Zn}, \mathrm{Ni}, \mathrm{Cu}, \mathrm{Fe}$ and Mn. It has been noted by (Qadir et al., 2000) concentration of cadmium is double in green vegetables showed that among all the vegetables, green leafy tissues store cadmium regarding double the maximum amount as that of the fruit portion. Because of the continuous use of sewage irrigation in Faisalabad, at some locations, wheat grain cadmium concentration exceeded beyond the (Ensink et al., 2004) maximum level. The chromium and lead in 12 vegetables receiving sewage water were $31-62$ and 3-13 times higher than the safe limits of 1.3 and $2.0 \mathrm{mg} / \mathrm{kg}$, respectively (Hussain, 2000; Hussain et al., 2006). Lead content in eatable parts of all the 12 vegetables was 37-93 times higher than maximum level of $0.3 \mathrm{mg} / \mathrm{kg}$ (Codex Alimentarius Commission, 2002). The fruit portions of several vegetables irrigated with sewage (Khan et al., 2007) had chromium and lead above permissible standards proposed by (Codex Alimentarius Commission, 2002).

\section{BENEFITS OF REUSE OF TREATED EFFLUENT WATER}

The use of treated sewage irrigation has several positive aspects. It not only, supplies nutrients to plants, also helps in improving yield of crop and reduces production costs because of the relatively high content of nutritional elements i.e. N, P, $\mathrm{K}$ and other micro-elements (Huang et al., 2003). The total $\mathrm{N}$ in the secondary TSW (Treated Sewage Water) is about 34 $\mathrm{mg} / \mathrm{l}$ in Beijing municipality (Wu et al., 2006). Increase in soil microbial activity was observed with sewage irrigation (Meli et al., 2002;). Different salad crops irrigated with the treated effluent, which had raised concentrations of inorganic nutrients, produced higher yields than similar crops irrigated with groundwater (Sheikh et al., 1987). Rice crops gave a higher yield when irrigated with raw or partially diluted sewage effluent compared to unamended groundwater (Chakrabarti, 1995).

Table 2: Showing various risks associated with use of sewage irrigation in agricultural sector

\begin{tabular}{|c|c|c|}
\hline Risks & Contamination & Reference \\
\hline $\begin{array}{l}\text { Pathogens } \\
\text { (Bacteria) }\end{array}$ & $\begin{array}{l}\text { Bacterial } \\
\text { Pathogen }\end{array}$ & $\begin{array}{l}\text { (Ensink et } \\
\text { al.,2004) }\end{array}$ \\
\hline $\begin{array}{c}\text { Bacteria } \\
\text { (recycled } \\
\text { water) }\end{array}$ & $\begin{array}{l}\text { Bacterial } \\
\text { Pathogen }\end{array}$ & $\begin{array}{l}\text { Toze, } \\
1999)\end{array}$ \\
\hline Virus & Pathogen Virus & $\begin{array}{l}\text { (Toze, } \\
1999)\end{array}$ \\
\hline $\begin{array}{c}\text { Virus } \\
\text { (infect } \\
\text { humans) }\end{array}$ & Pathogen Virus & $\begin{array}{c}\text { (Haas et al., } \\
\text { 1999) }\end{array}$ \\
\hline Protozoa & $\begin{array}{l}\text { Protozoan } \\
\text { Pathogen }\end{array}$ & $\begin{array}{c}\text { (Gennaccaro } \\
\text { et., 2003) }\end{array}$ \\
\hline Health & $\begin{array}{l}\text { Intense } \\
\text { infections } \\
\text { (Hookworm } \\
\text { infections) }\end{array}$ & $\begin{array}{l}\text { (Ensink et } \\
\text { al., 2004) }\end{array}$ \\
\hline Health & $\begin{array}{l}\text { Outbreak of } \\
\text { several diseases } \\
\text { - typhoid, fever, } \\
\text { viral hepatitis, } \\
\text { - helminthes } \\
\text { infections } \\
\text { (mostly } \\
\text { fascioliasis), } \\
\text { salmonella and } \\
\text { cholera }\end{array}$ & $\begin{array}{c}\text { (Bryan, } \\
1977)\end{array}$ \\
\hline $\begin{array}{l}\text { Heavy } \\
\text { metals }\end{array}$ & $\begin{array}{l}\text { - Metal toxicity } \\
\text { with sewage } \\
\text { irrigation } \\
\text { - Affecting } \\
\text { growth and } \\
\text { survival of } \\
\text { rhizobia } \\
\text { - Affecting }\end{array}$ & $\begin{array}{c}\text { (Chaudri et } \\
\text { al.,2000) }\end{array}$ \\
\hline
\end{tabular}




\begin{tabular}{|l|l|c|}
\hline & $\begin{array}{l}\text { legume } \\
\text { nodulation }\end{array}$ & \\
\hline Salinity & $\begin{array}{l}\text { - Increased } \\
\text { salinity with } \\
\text { sewage } \\
\text { irrigation } \\
\text {-Affecting soil } \\
\text { properties and } \\
\text { plant growth }\end{array}$ & \\
\hline
\end{tabular}

\section{Conclusion}

On the basis of currently available data or literature, we can conclude that the short-term application of sewage irrigation can be safe for the better productivity of crops without causing any harm to the soil properties. Generally, sewage water irrigation improved physico-chemical properties and fertility status of soils. The metallic cations contamination of vegetable crops was observed to be below the maximum permissible limits. However, several folds build-up of metallic cations in soils, leaves and roots of vegetable crops under study indicated that there might be an increase in metallic cations contamination beyond maximum permissible limit if sewage water, is continuously used for irrigation on long term. Thus, timely monitoring of sewage water, its effect on soil, crops is essential to maintain soil quality and for consumption of safe foods grown on them. Establishment of at least a primary sewage treatment plant is suggested where raw sewage is being diverted for irrigation to overcome the risks of sewage irrigation in agriculture sector.

Also, as per the findings of the current literature the long-term application of sewage irrigation to the agriculture section is not recommendable. Long term sewage irrigation may lead to phyto-toxicity problem in plants due to heavy metals, decreased bulk density, increased salinity, pathogens, increased chemical contaminants and decreased fertility conditions of the soil. These all can be controlled through treatment. Future research and development must focus on the treatment, recycled and potential use of sewage irrigation in the agriculture sector in order to meet the requirements of agriculture sector and to protect the diminishing fresh water resources. Also, there is urgent need of a well-coordinated program to create awareness for the potential benefits of sewage irrigation in agriculture.

\section{REFERENCES}

[1] Abdullah A., The future role of the use of sewage effluent for irrigation in the near east, Land and Water Development Division FAO-Rome-Italy.

[2] Ali H.M., El-Mahrouk E.M., Hassan Fatma A., Khamis M.H., (2010): Growth, Chemical Compositions and Soil Properties of Tipuana speciosa Irrigated with Sewage Effluent. The 25th Meeting of Saudi Biological Society. Nanotechnology in Life Sciences, Alasa City at King Faisal University.
[3] Anderson D.A. (2004): Environmental economics and natural resource management. P: 117-21. Thomson South-Western, USA.

[4] Bashir A., Khuda B., Sarfraz H. (2006): Effect of sewage water on spinach yield. International Journal of Agriculture \& Biology 1560-8530/2006/08-3-423-425.

[5] Bryan F. L. (1977): Diseases transmitted by foods contaminated by wastewater. J. Food Protec. 40(1): 45-56.

[6] Carr R.M., Blumenthal U.J., Mara D.D. (2004): Guidelines for the safe use of wastewater in agriculture: revisiting WHO guidelines. Water Sci. Technol, 50: 31-38.

[7] Chakrabarti C. (1995): Residual effects of long-term land application of domestic wastewater. Environ. Int, 21: 333-339.

[8] Chaudri A.M., Allain C.M.G., Jefferson V.L.B., Nicholson F.A., Chambers B.J., McGrath S.P., (2000): A study of the impacts of Zn and $\mathrm{Cu}$ on two rhizobial species in soils of a long-term field experiment. Plant Soil, 221: 167-179

[9] Codex Alimentarius Commission. (2002): Codex general standard for contaminants and toxins in foods. Report of the 34th Session of the Codex Committee on Food Additives and Contaminants. Rotterdam, The Netherlands, 11-15 March.

[10] CWC (2000): Water and related statistics. Information Systems Organization, Water Planning and Organization Wing, Central Water Commission, RK Puram, New Delhi 66: 451.

[11] Ensink J. H. J., Simmons R. W., Van der Hoek W. (2004): Wastewater use in Pakistan: The cases of Haroonabad and Faisalabad. In Scott Faruqui C. A., N. I., Raschid L. (eds.) Wastewater Use in Irrigated Agriculture: Confronting the Livelihood and Environmental Realities. CAB International, Wallingford, 91-99.

[12] Gennaccaro A.L., McLaughlin M.R., Quintero-Betancourt W., Huffman D.E., Rose J.B., (2003): Infectious Cryptosporidium parvum oocysts in final reclaimed effluent. Appl. Environ. Microbiol, 69: 4983-4984.

[13] Ghafoor A., Qadir M., Sadiq M., Murtaza G., Brar M.S. (2004): Lead, Copper, Zinc and Iron Contaminations in Soils and Vegetables Irrigated with City Effluent on Urban Agricultural Lands. J. Indian Society of Soil Sci, 52: 114-7

[14] Haas C.N., Rose J.B., Gerba C.P. (1999): Quantitative Microbial Risk Assessment. John Wiley and Sons, New York.

[15] Halliwell D.J., Barlow K.M., Nash D.M., (2001): A review of the effects of wastewater sodium on soil properties and their implications for irrigation systems. Aust. J. Soil Res, 39: 1259-1267.

[16] Hayssam Ali M., El-Sayed EL- Mahrouk M., Fatma Hassan A., Mohamed El-Tarawy A., (2011): Usage of sewage effluent in irrigation of some woody tree seedlings. Part 3: Swietenia mahagoni (L.) Jacq.

[17] Huang G.H., Zha G.F., Lin F., (2003): Water and N use efficiency for summer corn with irrigation by sewage effluent. In: Kang, S., Davies, B., Shan, L., Cai, H. (Eds.), Proceeding of Water-saving Agriculture and Sustainable Use of Water and Land Resources. Shaanxi Science Technology Publications, 652-658.

[18] Hussain S. I. (2000): Irrigation of crops with sewage effluent: Implications and movement of lead and chromium as affected by soil texture, lime gypsum and organic matter. Ph.D. Thesis, Dept. Soil Sci., Univ. Agri., Faisalabad, Pakistan.

[19] Hussain S. I., Ghafoor A., Ahmad S., Murtaza G. and Sabir M. (2006) Irrigation of crops with raw sewage: hazard and assessment in effluent, soil and vegetables. Pak. J. Agric. Sci, 43(3-4): 97-101.

[20] Jianwen Zou., Shuwei Liu., Yanmei Qin., Genxing Pan., Dawei Zhu. (2009): "Sewage irrigation increased methane and nitrous oxide emissions from rice paddies in southeast china. J. of Agriculture, Ecosystems and Environment, 129: 516-522.

[21] Jnad I., Lesikar B., Kenimer A., Sabbagh G. (2001): Subsurface drip dispersal of residencial effluent. I: Soil chemical characteristics. Trans. Am. Soc. Agric. Eng, 44(5): 1149-1157.

[22] Kaul S.N., Badrinath S.D., Juwarkar A.S., Satyanarayanan S., (1989): Asian Environ, 11: 33.

[23] Khan M. J., Bhatti A. U., Hussain S., Wasiullah. (2007): Heavy metal contamination of soil and vegetables with industrial effluents from sugar mills and tanneries. Soil Environ. 26(2): 139-145.

[24] Malla R., Tanaka Y., Mori K., Totawat K.L. (2007): Effect of short-term Sewage Irrigation on Chemical Build Up in Soils and Vegetables. The Agricultural Engineering International: the CIGR Journal. Manuscript L W 07006 Vol. IX.

[25] Mays D. A., Terman G. L., Duggan J. C. (1973): Municipal compost: effects on crop yield and soil properties. J. Water Poll. Contain. Fed, 45: 1851-1864.

[26] Meli S., Maurizio M., Belligno A., Bufo S.A., Mazzatura A., Scopa A. (2002): Influence of irrigation with lagooned urban wastewater on 
chemical and microbial soil parameters in a citrus orchard under Mediterranean condition. Sci. Total Environ, 285: 69-77.

[27] Ndour N.Y.B., Baudoin E., Guisse A., Seck M., Khouma M., Brauman A. (2008): Impact of irrigation water quality on soil nitrifying and total bacterial communities. Biol. Fertil. Soils, 44: 797-803.

[28] Owusu, V., Bakang, J.A., Abaidoo, R.C. et al. Perception on untreated wastewater irrigation for vegetable production in Ghana. Environ Dev Sustain 14, 135-150 https://doi.org/10.1007/s10668-011-9312-x

[29] Qadir M., Ghafoor A., Murtaza G. (2000): Cadmium concentration in vegetables grown on urban soils irrigated with untreated municipal sewage. Environ. Dev. Sustain, 2(1): 11-19.

[30] Sheikh B., Jaques R.S., Cort R.P. (1987): Reuse of tertiary municipal wastewater effluent for irrigation of raw eaten food crops: a 5 year study. Desal 67: 245-254.

[31] Singh A.K. (2003): Water resources and their availability. In: Souvenir, National Symposium on Emerging Trends in Agricultural Physics, Indian Society of Agrophysics, New Delhi, 18-29.

[32] Singh G., Bhati M. (2005): Growth of Dalbergia sissoo in desert regions of western India using municipal effluent and the subsequent changes in soil and plant chemistry. Bioresour. Technol, 96: 1019-1028.

[33] Thomas Gloaguen V., Cristina Forti M., Yves Lucas lia Ce., Montes R., Roberta A.B., Gon calves., Herpin Uwe., Adolpho Melfi J. (2007): Soil solution chemistry of a Brazilian Oxisol irrigated with treated sewage effluent. Agricultural water management 88: 119 - 131.

[34] Toze S. (1999): PCR and the detection of microbial pathogens in water and wastewaters. Water Res, 33: 3545-3556.

[35] USEPA (1992): U.S. EPA, Offices of Water and Wastewater and compliance (Ed.) Guidelines for water reuse. U.S. EPA, Washington. State Water Strategy.

[36] Wang X., Chen T., Liang R., Zhou Q. (2002): Effects of land utilization of sewage sludge on crops and soils, 13: 163-166.

[37] Williams D. E., Vlamis J., Pukite A. H. Corey J. E. (1980): Trace element accumulation, movement and distribution in the soil profile from massive applications of sewage sludge. Soil Sci, 129: 119-132.

[38] Wu C., Huang G., Liu H., Wu W., Xu C. (2006): Experimental investigation on heavy metals distribution in soil-crop system with irrigation of treated sewage effluent. Trans, CSAE 22(7): 91-96 (in Chinese, with English abstract)

[39] Xie Y.X., Xiong Z.Q., Xing G.X. (2007): Assessment of nitrogen pollutant sources in surface water of Taihu lake region. Pedosphere, 17(2): 200-208.

[40] Yadav R.K., Goyal B., Sharma R.K., Dubey S.K., Minhas, P.S. (2002): Post-irrigation impact of domestic sewage effluent on composition of soils, crops and ground water: a case study. Environ. Int, 28: 481-486.

[41] FAO. Wastewater Treatment and Use in Agriculture. Available Online: http://www.fao.org/docrep/T0551E/T0551E00.htm. https://doi.org/10.1007/s10668-011-9312-x.

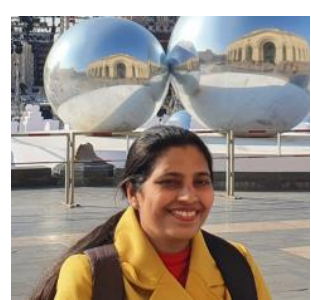

Monika Kharub, M.Sc., M.Tech, Ph.D, Freelance environment consultant and Independent Researcher (India). Monika's key areas of interest are analysis of water quality parameters, advanced oxidation processes for degradation of pesticides, solid waste management. She has published several research papers and book chapters in national and international conferences. She presented research paper in several national and international conferences. She received merit scholarship during M. Tech from Guru Harkrishan Educational Society, Chandigardh, India 